\title{
Timing of the first drainage of the Baltic Ice Lake synchronous with the onset of Greenland Stadial 1
}

Article

Accepted Version

Muschitiello, F., Lea, J. M., Greenwood, S. L., Nick, F. M., Brunnberg, L., MacLeod, A. and Wohlfarth, B. (2016) Timing of the first drainage of the Baltic Ice Lake synchronous with the onset of Greenland Stadial 1. Boreas, 45 (2). pp. 322-334. ISSN 0300-9483 doi: https://doi.org/10.1111/bor.12155 Available at https://centaur.reading.ac.uk/77198/

It is advisable to refer to the publisher's version if you intend to cite from the work. See Guidance on citing.

Published version at: http://dx.doi.org/10.1111/bor. 12155

To link to this article DOI: http://dx.doi.org/10.1111/bor.12155

Publisher: Wiley

All outputs in CentAUR are protected by Intellectual Property Rights law, including copyright law. Copyright and IPR is retained by the creators or other copyright holders. Terms and conditions for use of this material are defined in the End User Agreement.

www.reading.ac.uk/centaur 
Central Archive at the University of Reading

Reading's research outputs online 
1 Timing of the first drainage of the Baltic Ice Lake synchronous

2 with the onset of Greenland Stadial 1

3 FRANCESCO MUSCHITIELLO, JAMES M. LEA, SARAH L. GREENWOOD, FAEZEH M. NICK,

4 LARS BRUNNBERG, ALISON MACLEOD AND BARBARA WOHLFARTH

5 Muschitiello, F., Lea, J. M, Greenwood, S. L., Nick, F. M., Brunnberg, L., MacLeod, A., \&

6 Wohlfarth, B.: Timing of the first drainage of the Baltic Ice Lake synchronous with the

7 onset of Greenland Stadial 1 
8 Glacial varves can give significant insights into recession and melting rates of decaying

9 ice sheets. Moreover, varve chronologies can provide an independent means of

10 comparison to other annually resolved climatic archives, which ultimately help to

11 assess the timing and response of an ice sheet to changes across rapid climate

12 transitions. Here we report a composite 1257-year long varve chronology from south-

13 eastern Sweden spanning the regional late Allerød-late Younger Dryas pollen zone.

14 The chronology was correlated to the Greenland Ice Core Chronology 2005 using the

15 time-synchronous Vedde Ash volcanic marker, which can be found in both

16 successions. For the first time, this enables secure placement of the Lateglacial

17 Swedish varve chronology in absolute time. Geochemical analysis from new varve

18 successions indicate a marked change in sedimentation regime accompanied by an

19 interruption of ice-rafted debris deposition synchronous with the onset of Greenland

20 Stadial 1 (GS-1; 12846 years before 1950 AD). With the support of a simple ice

21 flow/calving model, we suggest that slowdown of sediment transfer can be explained

22 by ice-sheet margin stabilisation/advance in response to a significant drop of the Baltic

23 Ice Lake level. A reassessment of chronological evidence from central-western and

24 southern Sweden further supports the hypothesis of synchronicity between the first

25 (penultimate) catastrophic drainage of the Baltic Ice Lake and the start of GS-1 in

26 Greenland ice cores. Our results may therefore provide the first chronologically robust

27 evidence linking continental meltwater forcing to rapid atmosphere-ocean circulation 28 changes in the North Atlantic.

29 Francesco Muschitiello (Francesco.muschitiello@geo.su.se), Sarah L. Greenwood and 30 Barbara Wohlfarth, Department of Geological Sciences and Bolin Centre for Climate 
Brunnberg, Department of Physical Geography and Bolin Centre for Climate Research,

Geology, University Centre in Svalbard (UNIS), PO Box 156, NO-9171 Longyearbyen,

Norway, Centre for Ice and Climate, Niels Bohr Institute, University of Copenhagen,

2100 Copenhagen, Denmark; Alison MacLeod, Department of Geography, Royal

Holloway University of London, Egham, Surrey TW20 OEX, UK.

Understanding the timing and interplay between past ice-sheet dynamics and abrupt

climate change can be significantly enhanced where suitable highly resolved and independently dated palaeoenvironmental archives are available. Glacial varves are such a proxy, providing an indirect record for ice-marginal dynamics at potentially annual or sub-annual resolution. Furthermore, these records can provide lengthy and continuous chronologies, which can be directly compared to other climate archives. In turn, this allows the examination of potential couplings between changing regional ice-sheet behaviour and climate change.

The Swedish glacial varve chronology or 'Swedish Time Scale' (STS) provides a reconstruction preserving information regarding the dynamics and the melting of the Fennoscandian Ice Sheet (FIS). It is therefore an ideal data set to investigate ice sheet dynamics and sensitivity in response to climate change. The STS is based on visual cross-correlation of more than 1000 ice-proximal clastic varve-thickness successions,

51 which reflect the seasonal sediment input associated with the deglaciation of Sweden 52 (De Geer 1912, 1940). These clastic varves, with their distinct silt dominated summer 53 and clay dominated winter layers were deposited in the ice-dammed Baltic basin, the 
54 Baltic Ice Lake (BIL), and can today be found along the Baltic Sea coast and in the Baltic

55 Sea (Strömberg 1985; Cato 1987; Björck et al. 1992; Brunnberg 1995; Wohlfarth et al.

56 1994, 1995). The younger part of the STS is made up of postglacial delta sediments,

57 which were and still are deposited in the estuary of River Ångermanälven in northern

58 Sweden (Cato 1985, 1987, 1998; Wohlfarth et al. 1997). However, a putative gap of

59 700-900 varve years during the early and/or mid Holocene (Wohlfarth 1996;

60 Wohlfarth et al. 1997; Andrén et al. 1999), as well as difficulties in correlating varve

61 diagrams from Blekinge in southernmost Sweden to those of south-eastern Sweden

62 (Wohlfarth \& Possnert 2000) has so far posed a challenge to establishing an absolute

63 and continuous varve chronology from present back to >14 000 varve years. Given

64 the chronological uncertainties due to missing varves, each regional varve chronology

65 thus stands on its own (Wohlfarth \& Possnert, 2000).

The Lateglacial clay-varve diagrams from south-eastern Sweden (northern Småland and Östergötland) (Kristiansson 1986; Brunnberg 1995; Wohlfarth et al. $1993,1994,1995,1998)$, spanning the later part of the regional Allerød pollen zone $(A L)$ and the early part of the regional Younger Dryas pollen zone (YD), constitute one of the most valuable portions of the STS. This Lateglacial varve chronology (LGC) is

71 built by visual cross-correlations and corroborated by statistical analysis (Holmquist \& Wohlfarth 1998), but is at present only tentatively linked to a calendar-year time scale by means of ${ }^{14} \mathrm{C}$ dating (Goslar et al. 1999; Wohlfarth \& Possnert, 2000).

The recent finding of the Vedde Ash in a glacial varve succession from the same region (MacLeod et al. 2014) now offers an excellent opportunity to secure the

76 floating LGC chronology to an absolute time scale, and more importantly, to correlate 
accuracy this affords, the resulting correlation can therefore reveal crucial information regarding the temporal coupling between Fennoscandian ice-sheet dynamics and rapid climate change. Here we reassess, update and extend the 806-year long LGC from south-eastern Sweden (Wohlfarth et al. 1998), and link for the first time the FIS recession to the Greenland ice-core time scale. The existing chronology has, moreover, been complemented by new geochemical data and corroborated by idealised numerical modelling of ice dynamics. These help to cast light on the changes that occurred in the BIL terminating sector of the FIS around the onset of the YD. Our results highlight a possible linkage between changes in ice sheet behaviour associated with the drainage of the BIL and abrupt changes in atmosphere-ocean circulation in the North Atlantic domain.

\section{Study area and methods}

The LGC derives from sites located along the eastern edge of the southern Swedish Uplands. The terrain reaches $>330 \mathrm{~m}$ elevation above present-day sea level in the south and west of our area of interest, sloping eastwards and northwards towards the Baltic Sea (Fig. 1B, C). The FIS retreated broadly NW-wards across this region. Clayvarve chronologies have hitherto been the primary source of information regarding the pattern and timing of ice retreat (cf. Lundqvist \& Wohlfarth 2001). An absence of moraines across south-eastern Sweden suggests unpunctuated retreat, an exception 100 being the Vimmerby moraine that cuts across the south of our study area (Fig. 1C). 

et al. 2014). There is no further evidence of a sustained ice-margin position until the Middle Swedish End Moraine Zone (MSEMZ), a broad ( 10-20 km) zone stretching from Lake Vättern ENE across the Östergötland lowlands. Associated with the YD, the MSEMZ comprises moraines, deltas and glacio-tectonised successions linked with ice margin oscillations and an extremely slow rate of retreat (Kristiansson 1986; Lundqvist 108 1987).

Glacial lakes were impounded across south-eastern Sweden in front of the

110 retreating ice margin, both localised and linked to the much larger BIL, which was up111 dammed in the Baltic Sea Basin. The BIL was maintained by the ice dam across central-

112 southern Sweden and the southern Swedish uplands and the high threshold level in

113 Öresund; not until the ice margin retreated past Mt. Billingen could any drainage occur 114 (Björck 1995). A major (25 m lake-level drop) and rapid (1-2 years) drainage of the BIL, 115 and consequent opening to marine waters (Yoldia Sea stage), occurred at the end of 116 the YD when the Billingen ice dam was released (Björck \& Digerfeldt 1984; Björck 117 1995; Johnson et al. 2013). An earlier drainage is hypothesised to have occurred at the 118 late AL-YD transition (Björck 1995; Bennike \& Jensen 2013), but its magnitude and 119 dynamics are less well-constrained. Palaeo-shorelines of the BIL are evident along the 120 east and south coast of Sweden, rising to the north as a consequence of post-glacial 121 (and ongoing) glacio-isostatic rebound (see Fig. 1).

122 AL-age glacial varved-clay successions from sites close to the former highest 123 shoreline of the BIL had earlier been investigated in the provinces of Småland and 124 Östergötland (Kristiansson 1986; Wohlfarth et al. 1995, 1998) (Fig. 1). Most of the 125 varve thickness diagrams were obtained in a region that formed an archipelago-like 
landscape in the western part of the large BIL (Wohlfarth et al. 1998). The glacial

127 varves were thus deposited in fairly shallow waters (between $\sim 5$ and $70 \mathrm{~m}$ ) and mostly

128 within a large fjord complex (Fig. 1). Owing to isostatic uplift of the newly deglaciated

129 areas, progressive shallowing of the depositional basins along the coast and successive

130 isolation resulted in a cessation of varve deposition and replacement by homogeneous

131 clay and organic lacustrine sediments. The recently published varve chronology from

132 Gropviken (MacLeod et al. 2014) and the varve chronology from Sandfjärden (this

133 study), $\sim 50 \mathrm{~km}$ farther to the east, derive from sites that were located directly south

134 of the YD ice margin (Fig. 1) and at a former BIL water depth of approximately $100 \mathrm{~m}$ 135 (Brunnberg 1995).

Varve and ${ }^{14} \mathrm{C}$ chronologies

138 The original master chronology for Småland/Östergötland (the LGC) is a composite 139 chronology of 806 varve years (Wohlfarth et al. 1998; Wohlfarth \& Possnert 2000), 140 which is based on the visual linking of common and distinct sedimentological features 141 in 55 varve diagrams (Figs. 1, 2). These correlations are corroborated by cross142 correlation analysis (Holmquist \& Wohlfarth 1998). The chronology from Gropviken is 143 a 710 varve-year long record, which contains the Vedde Ash isochrone (MacLeod et 144 al. 2014). The chronology from Sandfjärden is a 623 varve-year long record (Fig. 1C). 145 AMS radiocarbon measurements that had been published earlier for selected 146 sites of the LGC (Wohlfarth et al. 1998; Wohlfarth \& Possnert 2000) are here used to 147 verify the internal consistency of the new composite varve chronology (Table 1). To 148 provide the most reliable ${ }^{14} \mathrm{C}$-based chronology, we selected only those ${ }^{14} \mathrm{C}$ 149 measurements that had been made on terrestrial plant macrofossil remains and we 
disregarded dates that were associated with unidentified and reworked plant material

151 or had analytical errors of $>250$ years (Wohlfarth et al. 1998; Wohlfarth \& Possnert 152 2000)

Based on Bayesian wiggle-match modelling using OxCal4.2 (Bronk Ramsey

154 2010), these ${ }^{14} \mathrm{C}$ dates were used to find the most likely possible placement of the LGC

155 on the IntCal13 radiocarbon calibration curve (Reimer et al. 2013). Outlying dates

156 were detected by the software applying the 'Outlier Analysis' and discarded until a

157 satisfactory and coherent age model was generated as defined by a high model 158 agreement with values higher than a threshold of 60\% (Bronk Ramsey 2009).

New cores: fieldwork, dating and elemental analyses

161 A new sediment succession from Lake Gummetorpasjön, which was previously 162 investigated by Wohlfarth et al. (1998), was cored in March 2015 (Fig. 1), with the 163 purpose of performing geochemical analysis. Parallel sediment cores were collected 164 using a 1-m long Russian corer with diameters of 10 and $7.5 \mathrm{~cm}$, obtaining $50 \mathrm{~cm}$ 165 overlapping sections.

166 Correlation to the previously established LGC chronology (Wohlfarth et al. 1998)

167 was carried out employing three distinct colour and varve thickness changes that were 168 identified by Wohlfarth et al. (1998). The marker layers, which occur 115 and 108 169 varve years apart from each other, are present in the majority of the varve diagrams 170 that compose the LGC, including Gummetorpajön (see discussion below). This allowed 171 the new XRF profiles to be placed unequivocally within the existing chronology. The new Gummetorpasjön sediment cores were scanned at the Department of 173 Geological Sciences at Stockholm University using an ITRAX XRF Core Scanner from 
Cox Analytical System (Gothenburg, Sweden) to detect chemical changes and signals

175 relating to summer and winter layers. Radiographic images were generated using a

176 Mo tube set at $55 \mathrm{kV}$ and $50 \mathrm{~mA}$ with a step size of $200 \mu \mathrm{m}$ and a dwell time of 400

177 ms. XRF data were acquired using a Mo tube set at $30 \mathrm{kV}$ and $50 \mathrm{~mA}$ with a step size

178 of $200 \mu \mathrm{m}$ and a dwell time of $30 \mathrm{~s}$. Based on XRF counting statistics of the new

179 Gummetorpasjön clay-varve record, reliable data were obtained for 21 elements with

180 signals well above the instrumental noise threshold making it unnecessary to

181 normalize the peak area data to the scattering. Relative changes in peak areas of

182 elemental data were therefore used to construct ratio profiles from selected

183 elements, i.e. $\mathrm{Zr}$, $\mathrm{Rb}, \mathrm{Fe}$ and $\mathrm{Ca}$. Elemental XRF core scanning profiles were used as

184 indicators of changes in sediment transfer rates and grain size mediated by local ice-

185 mass turnover within the fjord system.

\section{Results and discussion}

Reconstruction of the new Lateglacial varve chronology

189 To anchor the LGC to the chronology of Gropviken, which contains the Vedde Ash, we 190 approached the alignment systematically (see below), initially adopting Kristiansson's 191 (1986) original time scale.

The first step taken for correlating the Gropviken varve thickness diagram and

193 each one of the diagrams composing the LGC was to search for statistically significant 194 cross-correlations between the successions, though this proved unsuccessful due to 195 substantial differences in varve thicknesses.

We therefore introduced an additional alignment step by bridging Gropviken's 197 chronology and the LGC using the Sandfjärden floating varve chronology from the 
northern sector of Östergötland (Fig. 1C). The cross-correlation of varve thickness diagrams from Gropviken and Sandfjärden provided a statistically significant match ( $r$ $200=0.61$, signal-to-noise ratio $z=7.7, p=0.99)$ that enabled us to extend the varve 201 chronology to the northern sector of Östergötland (Fig. 3). In a next step we linked the Sandfjärden chronology to the LGC. However, crosscorrelations alone could not directly link the two chronologies together. The 204 chronologies were therefore aligned via identification of three common markers, i.e. 205 two colour changes at local varve years 2060 and 2169, and a characteristic thick varve 206 horizon at local varve year 2060 (Fig. 3). This technique (e.g. Palmer et al. 2010) 207 provided satisfactorily fits between the successions.

To provide an independent test of the alignment between the LGC and 209 Gropviken's chronology, we employed an independent ${ }^{14} \mathrm{C}$ dating method (Fig. 4). The 210 LGC is supported by AMS radiocarbon measurements (Wohlfarth et al. 1998;

211 Wohlfarth \& Possnert 2000), whereas the Vedde Ash has been precisely radiocarbon 212 dated in lake sediment records from western Norway (Lohne et al. 2013). The LGC was 213 anchored to the IntCal13 radiocarbon calibration curve using a Bayesian wiggle214 matching model based on eight radiocarbon dates. Using the calibrated age of the 215 Vedde Ash and the most likely placement of the LGC on the IntCal13 time scale, 216 respectively, we were able to calculate the offset between the chronology of 217 Gropviken and the LGC, and compare the results with the offset previously obtained 218 from the alignment approach. The offsets resulting from the two methods, 219 respectively, strongly agree with each other (-1353 years using the alignment versus 2201359 using wiggle-matching; Fig. 4), which indicates that the relative placement 221 between the northern and southern chronologies is coherent and reliable. 
Age error evaluation of the Lateglacial varve chronology

224 The excellent correlation among the 55 varve diagrams that compose the original LGC

225 suggests no or minimal counting errors and laterally continuous varve accumulation

226 over this sector of Småland/Östergötland (Wohlfarth et al. 1998). An example of such

227 region-wide chronological consistency is demonstrated by the precision of varve

228 counts in relation to the interval spanning the three marker horizons utilized to link

229 the original LGC to Sandfjärden's chronology ( $<1 \%$ difference).

The independent ${ }^{14} \mathrm{C}$ dating approach described in section above provides a

231 means to verify the chronological accuracy over a large interval of the LGC,

232 demonstrating that contributions to uncertainty from undetected systematic errors in

233 the varve layer identification process is minimal (Fig. 4). This is also substantiated by

234 the similarity between the inferred varve age and the unmodelled ${ }^{14} \mathrm{C}$-calibrated curve

235 (Fig. 4). Moreover, the biostratigraphic boundary of the AL-YD transition, which has

236 been identified in the pollen stratigraphy from Gummetorpasjön (Björck 1999),

237 provides an additional chronostratigraphic constraint that confirms the internal

238 consistency of the LGC. Indeed, even considering the low-resolution pollen sampling

239 (Björck 1999), the estimated ${ }^{14} \mathrm{C}$-calibrated age of this regionally isochronous marker

240 in the varve stratigraphy falls within the $1 \sigma$ range of the AL-YD pollen zone boundary

241 observed in some of the most robustly constrained radiocarbon-dated regional 242 records (Muschitiello \& Wohlfarth 2015).

We are confident that an overall uncertainty (entailing precision and accuracy)

244 of $\pm 0.5 \%(2 \sigma)$ is an over-conservative estimate for the unified chronology. This is based

245 on, i) the general lack of disturbed or suspicious intervals and the good preservation 
246 of the varves in all the LGC profiles (Wohlfarth et al. 1998), ii) the evenly high

247 correlation among numerous adjacent and distal sites (Wohlfarth et al. 1998), and iii)

248 the internal chronological consistency determined via independent dating

249 approaches. This is realistic given that the error that accompanies most varve

250 chronologies with well-developed and undisturbed successions displaying little

251 variations between alternate counts does not exceed $\pm 1 \%$ (Zolitschka et al. 2015).

254 Our new LGC extends over $1257 \pm 3$ varve years $(1 \sigma)$ and covers the interval from the 255 regional late $\mathrm{AL}$ pollen zone to the regional late YD pollen zone. The chronology is 256 based on 57 varve-thickness diagrams, which were compiled to form one unified 257 record of mean varve thickness (Fig. 5). The supporting ${ }^{14} \mathrm{C}$-based age model enables 258 us to secure the new LGC on the IntCal13 time scale. Critically, we are also now able 259 to synchronize the LGC record with the Greenland Ice-Core Chronology 2005 260 (Rasmussen et al. 2006; after converting the b2k age [before the year 2000] into BP 261 [before 1950 AD], hereafter GICC05 years BP) via the Vedde Ash time marker (Fig. 5). 262 This allows us, for the first time, to directly compare the dynamics of the FIS to the 263 Greenland ice-core event stratigraphy.

264 Although there are numerous distinct events with exceptionally thick varves, 265 Wohlfarth et al. (1998) identified only three major events in their varve chronology, 266 that are recurrent in the majority of the varve diagrams. The Events, numbered 1, 2 267 and 3 (Wohlfarth et al. 1998), are characterised by distinct colour changes of the clay 268 varves and based on the correlation to the ice core time scale occurred at 12847,12 269739 and 12624 GICC05 years BP, within one varve year. All the events exhibit a marked 
270 drop in varve thickness that lasts for a few decades. The colour change and the drop

271 in varve thickness make Event 1, 2 and 3 different from all the other anomalous varve 272 layers that can be observed in the new LGC.

273 Events 2 and 3, which are both preceded by an exceptionally thick varve, have 274 been attributed to drainages of ice-dammed lakes located west of the BIL (Wohlfarth 275 et al. 1998). These events are present in all varve diagrams except for Skedevi, Räfstad 276 and Kråkedal (sites 17, 20 and 21 in Fig. 1). As such, large areas above the highest 277 shoreline remained covered by stagnant ice and continued to contribute sediment 278 material to the BIL as the ice sheet retreated (Lundqvist \& Wohlfarth 2001). However, 279 it remains unclear why a decrease in varve thickness accompanies all of the events.

280 Event 1 in particular, which can be observed in all the varve diagrams covering this 281 interval (Figs. 1, 2), presents the most pronounced decrease in varve thickness of the 282 entire chronology, but is not preceded by a thick varve (Fig. 5). This suggests that the 283 causes of Event 1, which can be traced for more than $25 \mathrm{~km}$ eastwards (from 284 Gummetorpasjön to Tynn - Wohlfarth et al. 1998), are potentially not just a mere 285 response to a release of high amounts of sediment material into the BIL. Moreover, 286 based on a previously published ice-rafted debris (IRD) record (Wohlfarth et al. 1998) 287 that accompanies the LGC (Fig. 5), it is evident that, unlike Events 2 and 3, Event 1 is 288 the only one associated with a long-term interruption ( 130 varve years) in IRD 289 deposition. We note that, after synchronizing the varve record to the Greenland time scale, 291 Event 1 coincides with the transition from Greenland Interstadial 1 to Greenland 292 Stadial 1 (GS-1), which is defined in NGRIP ice cores as an abrupt shift in $d$-excess that 293 took place within 2-3 years (Steffensen et al. 2008). The onset of GS-1 is dated to 12 
$846 \pm 69$ GICCO5 years BP considering $1 \sigma$ age uncertainty in the GICC05 (i.e. half of the total maximum counting error - MCE; Rasmussen et al. 2006) and Event 1 is dated to $12847 \pm 2$ GICC05 years BP (accounting for $1 \sigma$ of the total uncertainty that accompanies the LGC). This places GS-1 and Event 1 at $725 \pm 6$ years and $726 \pm 2$ years, respectively, prior to the Vedde Ash in their respective records.

300 attention. In the following, we focus on the varve stratigraphic boundary identified at $30112847 \pm 71$ GICC05 years BP by reporting and discussing the results from XRF analyses 302 on Gummetorpasjön's succession in conjunction with output from idealised ice flow 303 model simulations.

(Fig. 6). Rb, which is common in several minerals, has generally low environmental mobility owing to strong sorption in clay minerals. Conversely, $\mathrm{Zr}$ is usually found in 309 medium to coarse silts and is present in heavy minerals. In fine-grained sediments 310 like in our clay varves, $\mathrm{Zr} / \mathrm{Rb}$ is thus an ideal proxy for grain size (Dypvik \& Harris 2001).

311 Like Rb, Fe absorbs onto clay and has relatively low mobility, whereas Ca can easily be 312 found in plagioclase and calcite in the sand and silt fraction (e.g. Johnson et al. 2013). 313 Thus, Fe/Ca can be used here as an additional indicator for grain size.

314 The XRF data profiles entirely resolve seasonal varves associated with summer 315 and winter accumulation, with summer laminae generally characterised by larger 316 grain sizes as compared to winter laminae (Fig. 6). The XRF stratigraphies consistently 317 show a decrease in grain size 18-19 varve years before Event 1 at 12847 GICC05 years 
BP (Fig. 6). At 12847 GICC05 years BP the ratio values abruptly shift indicating a change towards coarser grain sizes. The shift takes place within one varve year, after which the geochemical parameters indicate that depositional conditions directly enter into a new stable state for a period that lasted 57-58 varve years (Fig. 6). We infer increased sediment supply of fine sediments during the two decades

323 preceding Event 1, followed by a marked slowdown of sediment transfer and increase 324 in grain size at 12847 GICC05 years BP. This is coeval with a distinct drop in varve 325 thickness and disappearance of IRD (Fig. 5). The rapid change in varve thickness and 326 grain size suggest a potential large-scale shift in the lake circulation regime and/or 327 changes to how sediments are supplied to the lake. Stabilisation of the ice sheet's calving margin could achieve the observed 329 changes in IRD delivery. Increased stability can be driven by glacio-isostatic rebound 330 of the crust and commensurate reduction in the proglacial water depth (Gomez et al. 331 2010), though its gradual nature cannot explain the abrupt sedimentation changes 332 observed in the LGC records. Rather, we suggest that a rapid fall of the BIL water level, 333 reducing calving margin buoyancy, and therefore calving, acted to abruptly decrease 334 iceberg calving flux from the ice margin.

335 The coupling between a rapid lowering of the BIL and a general decrease in varve 336 thickness together with interruption of IRD deposition has been suggested for the final 337 drainage of the BIL around the YD-Preboreal transition (Andrén et al. 1999, 2002). We 338 therefore argue that the evidence in the LGC and in our geochemical records 339 associated with Event 1 represent a late AL drainage of the BIL (Björck 1995). This 340 would be caused by a recession of the southern margin of the FIS beyond the lake 
341 outlet. In the following, we explore the implications of this hypothesis by means of

342 simulations from a simple ice flow/calving model.

343

344 Ice-sheet response to Baltic Ice Lake drainage

345 A series of experiments simulating a highly idealised glacier calving margin were

346 undertaken using a well-established one-dimensional flow-line numerical model (Nick

347 et al. 2010) and applying a simple floatation based calving law (Vieli et al. 2001). These

348 were conducted to investigate changes in calving rate and terminus position following

349 a drop in lake level for a flat-bedded ice sheet. These experiments do not seek to

350 directly simulate the ice draining into the BIL, but rather illustrate the potential

351 dynamic response of an ice sheet that experiences a drop in its proglacial lake level.

352 The specifics of the model are discussed in detail elsewhere (e.g. Nick et al. 2010), with

353 relevant input parameters shown in Table 2.

354 The model is used to investigate calving and terminus response with respect to 355 three variables: basal roughness, initial bed depth, and size of lake-level drop. Three 356 basal roughness scenarios were tested, chosen to represent a smooth, medium and 357 rough sliding scenarios, with values defined within the range of those used for 358 contemporary Greenland modelling studies (e.g. Nick et al. 2013; Lea et al. 2014a, b).

359 Three initial bed elevations were also chosen, equivalent to the mean, $25^{\text {th }}$ and $75^{\text {th }}$ 360 percentile values of a transect spanning an estimated pre-YD ice margin, isostatically 361 depressed according to the Ice5G model (Peltier 2004). Finally, three different lake362 level drops were simulated $(10,20$ and $30 \mathrm{~m})$, based on current estimates of the 363 magnitude of the hypothesized pre-YD BIL drainage (Björck 1995; Bennike \& Jensen 364 2013). 

and terminus behaviour are shown in Fig. 7. These demonstrate that in all cases a drop

367 in lake level would cause both a reduction in calving compared to the pre-drainage

368 iceberg flux and an advance of the ice-calving terminus. However, the magnitude of these changes, ranging from $10 \%$ to $45 \%$, is highly dependent on the initial lake depth and size of the lake drop. While changes in calving are broadly unaffected by the basal

371 conditions of the ice stream, Fig. 7 also shows that rougher bed conditions limit how 372 far the glacier calving margin can advance following a lake level drop (though it should 373 be emphasised that these should not be equated to estimates of actual advance distances of FIS following lake drainage).

The results provide evidence that the proportional reduction in calving rates will have been greatest in shallow areas of the BIL. Larger drops in lake level result in greater proportional decreases in calving flux, as is consistent with the floatation calving law employed in the model. However, these larger drops would also increase the range of calving response between shallow and deeper areas of the BIL 380 terminating sectors of FIS.

Model results suggest that the BIL terminating sectors of the FIS will have experienced a decrease in calving flux due to decreased buoyancy (and hence stabilisation) of the ice margin. Although calving rates will have responded almost 384 instantaneously to a drop in lake level, this is likely to only impact IRD frequency (as identified) rather than the deposition of finer grained sediments on a lake-wide scale. By itself, this can only partially explain the observed drop in IRD frequency, though it is worth noting that a thinner calving margin would also produce smaller, and therefore less long-lived icebergs. Faster melting icebergs would therefore decrease 

the probability of IRD deposition in ice distal/sheltered parts of the post-drainage BIL. A further consideration is that changes in lake circulation resulting from the drop in BIL may have caused debris-laden icebergs to be diverted elsewhere from the coring 392 sites.

The presence of thinner varves following the drainage suggests that reworking of material from newly exposed areas of the former lake bed did not result in significant sediment supply into the lake basin. We therefore hypothesise that the shift in observed sedimentation rates resulted from a rapid change in the delivery rate of subglacially derived material to the lake. However, further investigation regarding the major sediment sources for the varves would be required for this to be fully substantiated.

402 During the latter part of the AL, rapid deglaciation of the southern FIS margin near Mt. 403 Billingen - in the south-central Swedish low-land area (Fig. 1B) - is thought to have 404 generated a spillway system that connected the BIL to the sea in the west (e.g. Björck 405 \& Möller 1987; Björck 1995; Lundqvist \& Wohlfarth 2001). A rapid retreat of the FIS 406 west of the outlet resulted in a 5-10 m lowering of the BIL (Björck 1995) also referred 407 to as the first drainage of the BIL. Although this drainage hypothesis has long been debated, new reconstructions support the occurrence of a late AL connection between the BIL and the North Atlantic

410 (Swärd et al. 2015) and a significant drop of the BIL water level at this time (Bennike 411 \& Jensen 2013). Shore displacement curves from Hunneberg, west of Mt. Billingen, 412 provide a detailed framework for the timing of the deglaciation near the outlet and 
413 the freshwater connection to the sea (e.g. Björck \& Digerfeldt 1982a, b). The published

414 radiocarbon dates associated with the shoreline reconstructions have recently been

415 re-calibrated and combined using a Bayesian framework (Muschitiello et al. in press).

416 The radiocarbon dates indicate lake isolations from the sea near $11000{ }^{14} \mathrm{C}$ years BP

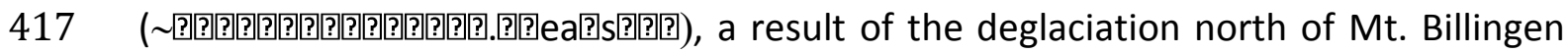

418 (Björck \& Digerfeldt 1982a, b). Therefore, the dates provide a chronological estimate 419 of the opening of the outlet at Mt. Billingen.

420 The combined age probability of the radiocarbon dates associated with lake

421 isolations has been compared to the age estimate of Event 1 derived from the 422 radiocarbon-based age model that underpins the LGC (Fig. 8). The two independent 423 age estimates, based on wiggle-matching and on radiocarbon calibration, are 424 remarkably similar $(12867 \pm 66$ cal. years BP for the opening of the outlet at Mt. 425 Billingen versus $12876 \pm 22$ cal. years BP for Event 1). The good chronological 426 correspondence supports our hypothesis of late AL drainage of the BIL synchronous 427 with the start of GS-1 in the Greenland ice core chronology. Furthermore, the 428 observed offset of $30 \pm 22$ years $(1 \sigma)$ between the GICCO5 and the IntCal13 time scales

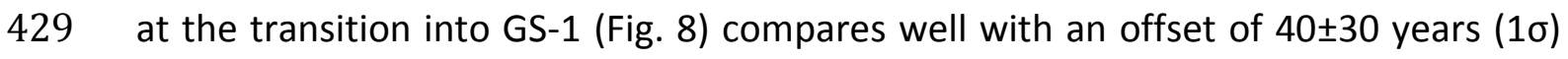
430 estimated with other independent methods of time-scale synchronization (Muscheler 431 et al. 2014).

432 We suggest that Event 1 can provide a precise chronological tie point that can 433 facilitate regional correlations for future varve reconstructions. In addition, this 434 stratigraphic marker - and more broadly any direct evidence of the first drainage of 435 the BIL - can potentially be used as an isochronous horizon to link records from the 
Baltic Sea, southern Sweden and the eastern sector of the North Sea downstream of

437 the drainage route.

\section{Palaeoclimatic implications}

440 The abrupt shift in $d$-excess values that marks the onset of GS-1 in the NGRIP ice cores

441 (Steffensen et al. 2008) can be ascribed to a large southward shift of the marine 442 moisture source for Greenland precipitation (Pfahl \& Sodemann 2014) driven by a 443 southward displacement of the North Atlantic westerly winds (Muschitiello et al. in 444 press). It has been hypothesised that such an abrupt southward diversion of the 445 westerly winds could have been triggered by a comparably abrupt westward 446 expansion of sea ice in the Nordic Seas (Muschitiello et al. in press). However, the 447 driving forces behind this putative swift growth of regional sea ice are still not entirely 448 discerned.

449 A catastrophic drainage of freshwater from the BIL can provide a plausible 450 explanation for a westward migration of sea ice in the Nordic Seas, and especially for 451 its abruptness, thereby providing a physical mechanism and timing for the start of GS452 1. We hypothesize that a powerful surge of Baltic-sourced freshwater routed north 453 along the coast of the Norwegian Sea could have increased sea-ice production and 454 moved, to some extent, sea ice off the shelf area towards the open ocean or 455 recirculated ice in the Nordic Seas. Thus, the excess sea ice was displaced westwards 456 beyond the limits expected from local climatological growth conditions and ultimately 457 exported to the subpolar North Atlantic. This phenomenon could have induced the 458 atmospheric circulation to cross thresholds beyond which the seasonal distribution of 459 sea ice in the Nordic Seas became significantly altered, instigating a widespread 
expansion of sea ice in the North Atlantic. Nonetheless, this explanation remains

461 speculative until more detailed climate modelling studies surrounding the

462 atmosphere-ocean response to Fennoscandian meltwater outlets can be undertaken.

463

\section{Conclusions}

465 In this study we have revaluated and extended a Swedish Lateglacial varve chronology, 466 which now forms a continuous 1257-year long record spanning the period from the 467 regional late $\mathrm{AL}$ to the late YD pollen zone. The chronology has been secured to the 468 GICC05 and IntCal13 absolute time scales. Correlation to the Greenland ice-core 469 framework allows us, for the first time, to compare the melting history of the FIS with 470 ice-core climate events.

By using geochemical analyses and ice-flow modelling simulations, we suggest

472 that in the late AL a major drop of the BIL water level associated with the first drainage

473 of the BIL occurred. The drainage took place synchronously with the start of GS-1 and 474 specifically $726 \pm 2$ years prior to the deposition of the Vedde Ash as compared to $475725 \pm 6$ years observed in ice-core records. The drainage event would provide a 476 plausible physical explanation for the timing and sign of hydroclimatic shifts observed 477 in the Greenland records, while the related stratigraphic marker can serve as an 478 important chronological tie-point for future regional correlation of proxy records.

We hope that this study will inspire future water-hosing and eddy-resolving 480 ocean model simulations that can help to shed light on the forcing mechanisms behind 481 the rapid climate changes that took place at the inception of Greenland Stadial 1 in 482 the North Atlantic region. 
Acknowledgements. - We are kindly grateful to P. Saarikoski for assistance during fieldwork and M. Kylander for help with XRF core scanning. We are also grateful to M.D. Johnson and an anonymous reviewer for helpful comments on an earlier version of the manuscript. The contribution of JL was supported by FORMAS grant 214-20131600 (PI: Nina Kirchner, Stockholm University). This work is a contribution to the INTIMATE project.

\section{References}

Andrén, T., Björck, J. \& Johnsen, S. 1999: Correlation of Swedish glacial varves with the Greenland (GRIP) oxygen isotope record. Journal of Quaternary Science 14, 361371.

Andrén, T., Lindeberg, G. \& Andrén, E. 2002: Evidence of the final drainage of the Baltic Ice Lake and the brackish phase of the Yoldia Sea in glacial varves from the Baltic Sea. Boreas 31, 226-238.

Anjar, J., Larsen, N.K., Håkansson, L., Möller, P., Linge, H., Fabel, D. \& Xu, S. 2014: A ${ }^{10} \mathrm{Be}$-based reconstruction of the last deglaciation in southern Sweden. Boreas $43,132-148$.

Bennike, O. \& Jensen, J.B. 2013: A Baltic Ice Lake lowstand of latest Allerød age in the Arkona Basin, southern Baltic Sea. Geolological Survey of Denmark and Greenland Bulletin 28, 17-20.

Björck, S. 1979: Late Weichselian stratigraphy of Blekinge, SE Sweden, and water level changes in the Baltic Ice Lake. LUNDQUA Thesis 7, 248 pp.

Björck, J. 1999. The Allerød-Younger Dryas pollen zone boundary in an 800-year varve chronology from southeastern Sweden. GFF 121, 287-292.

Björck, S., 1995: A review of the history of the Baltic Sea, 13.0-8.0 ka BP. Quaternary International 27, 19-40.

Björck, S. Digerfeldt, G., 1982a: New 14C dates from Hunneberg supporting the revised deglaciation chronology of the Middle Swedish end moraine zone. GFF 103, 395404.

Björck, S. Digerfeldt, G., 1982b: Late Weichselian shore displacement at Hunneberg, southern Sweden, indicating complex uplift. GFF 104, 131-155. 
Björck, S. \& Digerfeldt, G. 1984: Climatic changes at Pleistocene/Holocene boundary in the Middle Swedish End Moraine Zone, mainly inferred from stratigraphic indications. In Mörner, N.A., Karlén, W. (eds): Climatic Changes on a Yearly to Millennial Basis. Reidel Publishing Co., Dordrecht, pp37-56.

Björck, S. \& Möller, P. 1987: Late Weichselian environmental history in southeastern Sweden during the deglaciation of the Scandinavian ice sheet. Quaternary Research 28, 1-37.

Björck, S., Cato, I., Brunnberg, L. \& Strömberg, B. 1992: The clay-varve based Swedish Time Scale and its relation to the Late Weichselian radiocarbon chronology. In The Last Deglaciation: Absolute and Radiocarbon Chronologies, 25-44. Springer, Berlin.

Bronk Ramsey, C. 2009: Bayesian analysis of radiocarbon dates. Radiocarbon 51, 337360.

Bronk Ramsey, C. 2010: OxCal Program, v. 4.1.7, Radiocarbon accelerator unit, University of Oxford, UK.

Brunnberg, L. 1995: Clay-varve chronology and deglaciation during the Younger Dryas and Preboreal in the easternmost part of the Middle Swedish Ice Marginal Zone. Quaternaria Series A 2, 1-95.

Cato, I. 1985: The definitive connection of the Swedish geochronological time scale with the present, and the new date of the zero year in Döviken, northern Sweden. Boreas 14, 117-122.

Cato, I. 1987: On the definitive connection of the Swedish Time Scale with the present. Sveriges Geologiska Undersökning Ca 68. 55 pp.

Cato, I. 1998: Ragnar Lidén's Postglacial Varve Chronology from the Ångermanälvan Valley, Northern Sweden. Sveriges Geologiska Undersökning Ca 88.82 pp.

Cuffey, K.M. \& Paterson, W.S.B. 2010: The physics of glaciers. 704 pp. ButterworthHeinemann, Oxford.

De Geer, G. 1912: Geochronology of the last 12,000 years. Proceedings of the International Geological Congress 1910, 241-253.

De Geer, G. 1940. Geochronologia Suecica Principles. Kungliga Svenska Vetenskapsakademiens Handligar, Tredje Serien Band 18, No. 6, 367 pp.

Dypvik, H. \& Harris, N.B. 2001: Geochemical facies analysis of fine-grained siliciclastics using Th/U, $\mathrm{Zr} / \mathrm{Rb}$ and ( $\mathrm{Zr}+\mathrm{Rb}) / \mathrm{Sr}$ ratios. Chemical Geology 181, 131-146.

Gomez, N., Mitrovica, J.X., Huybers, P. \& Clark, P.U. 2010: Sea level as a stabilizing factor for marine-ice-sheet grounding lines. Nature Geoscience 3, 850-853. 
Goslar, T., Wohlfarth, B., Björck, S., Possnert, G. \& Björck, J. 1999: Variations of atmospheric $14 \mathrm{C}$ concentrations over the Allero $\varnothing \mathrm{d}$-Younger Dryas transition. Climate Dynamics 15, 29-42.

Holmquist, B. \& Wohlfarth, B. 1998: An evaluation of the Late Weichselian Swedish varve chronology based on cross-correlation analysis. GFF 120, 35-46.

Johnsen, T.F., Alexanderson, H., Fabel, D. \& Freeman, S.P.H.T. 2009: New ${ }^{10} \mathrm{Be}$ cosmogenic ages from the Vimmerby moraine confirm the timing of Scandinavian Ice Sheet deglaciation in southern Sweden. Geografiska Annaler $91 A, 113-120$.

Johnson, M.D., Kylander, M.E., Casserstedt, L., Wiborgh, H. \& Björck, S. 2013: Glaciomarine varved clay in central Sweden before and after the Baltic Ice Lake drainage: a further clue to the drainage events at Mt Billingen. GFF 135, 293307.

Kristiansson, J. 1986: The ice recession on the southeastern part of Sweden. Stockholm, University of Stockholm, Department of Quaternary Research, Report 7, $133 \mathrm{pp}$.

Lea, J. M., Mair, D. W., Nick, F. M., Rea, B. R., Weidick, A., Kjaer, K. H., Morlighem, M., Van As, D. \& Schofield, J. E. 2014: Terminus-driven retreat of a major southwest Greenland tidewater glacier. Journal of Glaciology, 60, 333-344.

Lea, J.M., Mair, D.W.F., Nick, F.M., Rea, B.R., As, D.V., Morlighem, M., Nienow, P. \& Weidick, A. 2014: Fluctuations of a Greenlandic tidewater glacier driven by changes in atmospheric forcing: observations and modelling of Kangiata Nunaata Sermia, 1859-present. The Cryosphere, 8, 2031-2045.

Lohne, O.S., Mangerud, J. \& Birks, H.H. 2013: Precise 14C ages of the Vedde and Saksunarvatn ashes and the Younger Dryas boundaries from western Norway and their comparison with the Greenland Ice Core (GICC05) chronology. Journal of Quaternary Science 28, 490-500.

Lundqvist, J. 1987: Glaciodynamics of the Younger Dryas marginal zone in Scandinavia. Implications of a revised glaciation model. Geografiska Annaler 69A, 305-319.

Lundqvist, J. \& Wohlfarth, B. 2001: Timing and east-west correlation of south Swedish ice marginal lines during the Late Weichselian. Quaternary Science Reviews 20, 1127-1148.

Macleod, A., Brunnberg, L., Wastegård, S., Hang, T. \& Matthews, I.P. 2014: Lateglacial cryptotephra detected within clay varves in Östergötland, south-east Sweden. Journal of Quaternary Science 29, 605-609. 
Muscheler, R., Adolphi, F. \& Knudsen, M.F. 2014: Assessing the differences between the IntCal and Greenland ice-core time scales for the last 14,000 years via the common cosmogenic radionuclide variations. Quaternary Science Reviews 106, 81-87.

Muschitiello, F. \& Wohlfarth, B. 2015: Time-transgressive environmental shifts across Northern Europe at the onset of the Younger Dryas. Quaternary Science Reviews 109, 49-56.

Muschitiello, F., Pausata, F.S.R., Watson, J.E., Smittenberg, R.H., Salih, A.A.M., Brooks, S.J., Whitehouse, N.J. Karlatou-Charalampopoulou, A. \& Wohlfarth, B. in press: Fennoscandian freshwater control on Greenland hydroclimate shifts at the onset of the Younger Dryas. Nature Communications.

Nick, F.M., Van der Veen, C.J., Vieli, A. \& Benn, D.I. 2010: A physically based calving model applied to marine outlet glaciers and implications for the glacier dynamics. Journal of Glaciology, 56, 781-794.

Nick, F.M., Vieli, A., Andersen, M.L., Joughin, I., Payne, A., Edwards, T.L. \& van de Wal, R.S. 2013: Future sea-level rise from Greenland/'s main outlet glaciers in a warming climate. Nature, 497, 235-238.

Palmer, A.P., Rose, J., Lowe, J.J. \& MacLeod, A. 2010: Annually resolved events of Younger Dryas glaciation in Lochaber (Glen Roy and Glen Spean), Western Scottish Highlands. Journal of Quaternary Science, 25, 581-596.

Peltier, W.R. 2004: Global glacial isostasy and the surface of the ice-age Earth: the ICE5G (VM2) model and GRACE. Annual Reviews of Earth and Planetary Sciences 32, 111-149.

Pfahl, S. \& Sodemann, H. 2014: What controls deuterium excess in global precipitation? Climate of the Past 10, 771-781.

Rasmussen, S.O., Andersen, K.K., Svensson, A.M., Steffensen, J.P., Vinther, B.M., Clausen, H.B., Siggaard-Andersen, M.L., Johnsen, S.J., Larsen, L.B., Dahl-Jensen, D., Bigler, M., Röthlisberger, R., Fischer, H., Goto-Azuma, K., Hansson, M.E. \& Ruth, U. 2006: A new Greenland ice core chronology for the last glacial termination. Journal of Geophysical Research: Atmospheres 111, D061202.

Reimer, P.J., Bard, E., Bayliss, A., Beck, J.W., Blackwell, P.G., Bronk Ramsey, C., Buck, C.E., Cheng, H., Edwards, R.L. \& Friedrich, M. 2013: IntCal13 and Marine13 radiocarbon age calibration curves 0-50,000 years cal BP. Radiocarbon 55,18691887.

Steffensen, J.P., Andersen, K.K., Bigler, M., Clausen, H.B., Dahl-Jensen, D., Fischer, H., Goto-Azuma, K., Hansson, M., Johnsen, S.J., Jouzel, J., Masson-Delmotte, V., Popp, T., Rasmussen, S.O., Rothlisberger, R., Ruth, U., Stauffer, B., SiggaardAndersen, M.-L., Sveinbjrnsdottir, A.E., Svensson, A. \& White, J.W.C. 2008: High- 
Resolution Greenland Ice Core Data Show Abrupt Climate Change Happens in Few Years. Science 321, 680-684.

Swärd, H., O’Regan, M., Ampel, L., Ananyev, R., Chernykh, D., Flodén, T., Greenwood, S.L., Kylander, M.E., Mörth, C.M., Preto, P. \& Jakobsson, M. 2015: Regional deglaciation and postglacial lake development as reflected in a 74 m sedimentary record from Lake Vättern, southern Sweden. GFF, 1-19.

Vieli, A., Funk, M. \& Blatter, H. 2001: Flow dynamics of tidewater glaciers: a numerical modelling approach. Journal of Glaciology, 47, 595-606.

Wohlfarth, B. 1996: The chronology of the last termination: a review of radiocarbondated, high-resolution terrestrial stratigraphies. Quaternary Science Reviews 15, 267-284.

Wohlfarth, B. \& Possnert, G. 2000: AMS radiocarbon measurements from the Swedish varved clays. Radiocarbon 42, 323-334.

Wohlfarth, B., Björck, S., Possnert, G., Lemdahl, G., Brunnberg, L., Ising, J., Olsson, S. \& Svensson, N.-O. 1993: AMS dating Swedish varved clays of the last glacial/interglacial transition and the potential/difficulties of calibrating Late Weichselian "absolute"chronologies. Boreas 22, 113-128.

Wohlfarth, B., Björck, S., Holmqvist, B., Lemdahl, G. \& Ising, J. 1994: Ice recession and depositional environment in the Blekinge archipelago of the Baltic Ice Lake. GFF 116, 3-12.

Wohlfarth, B., Björck, S. \& Possnert, G. 1995: The Swedish time scale; a potential calibration tool for the radiocarbon time scale during the late Weichselian. Radiocarbon 37, 347-359.

Wohlfarth, B., Björck, S., Cato, I. \& Possnert, G. 1997: A new middle Holocene varve diagram from the river Ångermanälven, northern Sweden: indications for a possible error in the Holocene varve chronology. Boreas 26, 347-353.

Wohlfarth, B., Björck, S., Possnert, G. \& Holmquist, A.N.D.B. 1998: 800-year long, radiocarbon-dated varve chronology from south-eastern Sweden. Boreas 27, 243-258.

Zolitschka, B., Francus, P., Ojala, A.E.K. \& Schimmelmann, A. 2015: Varves in lake sediments - a review. Quaternary Science Reviews 117, 1-41.

\section{Figure and Table captions}


Figure 1. A. Locations of southern Sweden and NGRIP ice cores. B, C. Location of the sites used to construct the new Lateglacial varve chronology in southern Sweden.

660 Black circles refer to sites studied by Wohlfarth et al. (1995). Red circles refer to sites 661 studied by Kristiansson (1986). Blue numbers indicate the sites where the depositional 662 Event 1 (Wohlfarth et al. 1998) was identified (see text for details). Note that Event 1 663 can be observed in all the varve diagrams that cover the related time interval. Ice 664 marginal positions are based on Lundqvist \& Wohlfarth (2001) and visual 665 interpretation of moraine positions from the LiDAR-based topography. The 666 southernmost ice marginal line refers to the Younger Dryas ice limit (YD). The 667 northernmost ice marginal line refers to the ice limit shortly before the last drainage 668 of the Baltic Ice Lake. Highest shoreline data from Geological Survey of Sweden on a 669 colour scale graded according to present-day elevation (highest lake position was 670 time-transgressive: yellow to red). 1= Bjärka-Säby; $2=$ Skaggebo; $3=$ Nåtvin; 4= 671 Vårdnäs; 5= Järnlunden/Stensvassa; 6= Limmern; 7= Storsjön; 8, 9= Mjölsjön; 10= 672 Järnlunden/Sonebo; 11= Bjärsjön; 12, 13, 14= Glottern; 15= Eknäs; 16= Rimforsa; 17= 673 Skedevi; 18= Ytterbo; 19= Räfstad; 20= Äfsinge; 21= Åsunden/Krågedal; 22= Vigerstad; $67423=$ Hägerstad; 24= Rävantorpasjön; 25= Lillsjön; 26= Drättinge; 27= Boda; 28= 675 Årteryd; 29= Utdala; 30= Stjärnevik; 31= Tynn/Tyllinge; 32= Tynn/Draboviken; 33= 676 Nedre Emmaren; 34= Bjuggö; 35= Kärra; 36= Lövdalen; 37= Gumhem; 38= Långebro; 677 39, 40, 41= Hargsjön ; 42= Hargsjön 1; 43= Kisa; 44, 45= Adlerskogsjön; 46, 47= 678 Gummetorpasjön ; 48= Kristineberg; 49= Greby; 50= Åby; 51= Väsby; 52= Dråpetorp; $67953=$ Brunebo; 54= Järpekullen; 55= Kåreda. The location of Gropviken and Sandfjärden 680 is also shown (green circles). LiDAR topography (C) Lantmäteriet. 
682

683

684

685

686

687

688

689

690

691

692

693

694

695

696

697

698

699

700

701

702

703

704

Figure 2. Length of the varve-thickness diagrams used to construct the chronology presented in Wohlfarth et al. (1998) and displayed on the local varve time scale proposed by Kristiansson (1986). The chronology is based on diagrams studied by Kristiansson (1986) and Wohlfarth et al. (1995), which were visually and statistically cross-correlated with each other (Holmqvist \& Wohlfarth 1998). Numbers refer to the original coding scheme used by Holmqvist \& Wohlfarth (1998). The three major depositional events identified by Wohlfarth et al. (1998) are also shown at the bottom. The events are characterised by distinct colour changes of the clay varves and a marked drop in varve thickness that last for a few decades (see text for details).

Figure 3. Varve-width and stratigraphic alignment of the varve records forming the new composite Lateglacial varve chronology from Småland/Östergötland presented on the local varve time scale (Kristiansson 1986). The two northernmost successions of Gropviken and Sandfjärden were first cross-correlated with each other. Prior to cross-correlation time series were detrended applying a $16^{\text {th }}$ degree Fourier transform, filtered using a 3-year moving average and removing the first 10 bottom varves, and normalized by their standard deviation. The correlation coefficient $(r)$ and statistics (signal-to-noise ratio $z$ and $p$-value) between the individual records are given in the graph. Sandfjärden's chronology was correlated to the 806-year long master chronology (Wohlfarth et al. 1998) via common stratigraphic markers (two marked colour changes and an exceptionally thick varve layer). The master chronology presented here was filtered by removing the first 10 bottom varves of each varve diagram. 
Figure 4. Top panel: Wiggle-matching age model of the Lateglacial varve chronology (LGC) and verification of its placement relative to the chronology of Gropviken containing the Vedde Ash time marker. The age model of the LGC is based on radiocarbon dates from selected terrestrial plant macrofossils previously published in Wohlfarth et al. (1998) (blue crosses; Table 1). A radiocarbon-based calendar age for

711 the Vedde Ash in Gropviken (red cross) was assigned using precise estimates from 712 Lake Kråkenes in Western Norway (Lohne et al. 2013). The most likely position of each 713 radiocarbon estimate on the modelled IntCal13 calibration curve (grey; Reimer et al. 714 2013) is shown. In the upper-left panel is presented the comparison of the estimated 715 offsets between the LGC and Gropviken using cross-correlation and radiocarbon716 based methods, respectively (see text for details). The goodness of the placement of 717 the LGC relative to Gropviken is further confirmed by the position of the Allerød718 Younger Dryas pollen-defined boundary on the master chronology, which is consistent 719 with previously reported age estimates for this biostratigraphic event (Muschitiello \& 720 Wohlfarth 2015). The probability distribution functions of the most likely placement 721 on the IntCal13 time scale of the LGC and the Vedde Ash, respectively, are also shown 722 together with their 2 sigma standard error. Bottom panel: Plot showing varve-age 723 against depth (blue dots and dashed line). The varve-age-depth relationship is 724 compared to the calibrated ${ }^{14} \mathrm{C}$ curve based on the unmodelled radiocarbon 725 measurements listed in Table 1 (black dots). Bars indicate 2 sigma standard error 726 associated with each measurement and the additional varve-age error related to 727 macrofossil sampling (Wohlfarth et al. 1998). The varve-age scale is based on 728 synchronization to the IntCal13 time scale using the radiocarbon-based age estimate 729 of the Vedde Ash (red dot). 
731 Figure 5. The new Lateglacial varve chronology presented as a unified record of mean

732 varve thickness and plotted against the GICC05 time scale (after converting the b2k

733 age into BP) and IntCal13 time scale after synchronization via the Vedde Ash isochron

734 and wiggle-match modelling, respectively. Mean annual varve widths are displayed

735 together with a 10-year running average (red line). The chronology is plotted with a

736 record of ice-rafted mineral debris (blue histogram) formerly published in Wohlfarth

737 et al. (1998). The vertical dashed lines indicate the interval analysed for ice-rafted

738 debris grains. The three major depositional events identified by Wohlfarth et al. (1998)

739 are also displayed. The green bar shows the timing of the regional AL-YD pollen

740 boundary as defined in the Lateglacial varve chronology (Björck, 1999), which lags the

741 onset of Greenland Stadial 1 by $\sim 150$ years.

743 Figure 6. XRF elemental results from new Gummetorpasjön's varve records. All data 744 are smoothed using a 10-point running mean to facilitate visualization (black line). For 745 reference, the XRF data are presented with the optical and radiographic 746 stratigraphies. The stratigraphic transition referred to as Event 1 and synchronous 747 with the start of Greenland Stadial 1 in ice-core records is highlighted by the red 748 dashed line. The XRF elemental profiles consistently show relative changes in ratio 749 values 18-19 varve years before Event 1 (shaded area). Note inverse axis for $\mathrm{Zr} / \mathrm{Rb}$ 750 ratios.

752 Figure 7. Results of idealised model runs showing change in calving fluxes and 753 terminus position 10 years after an instantaneous drop in lake level is applied. These 
754 are shown for three different initial lake levels, and three different potential lake level

755 drops. These experiments were run for (A) low, (B) medium, and (C) high basal 756 roughness scenarios.

758 Figure 8. Calendar age of Event 1 in the new Lateglacial varve chronology relative to 759 the GICCO5 and IntCal13 time scale and compared with estimated age of the start of 760 Greenland Stadial 1 in Greenland ice cores. The age of Event 1 is also compared with 761 the combined probability of a number of calibrated radiocarbon dates constraining 762 the timing of the first drainage of the Baltic Ice Lake and presented in Muschitiello et 763 al. (in press). The calibrated radiocarbon dates refer to lake isolations from the sea, 764 which indicate timing of deglaciation of the outlet system west of Mount Billingen in 765 southern Sweden, near $11000{ }^{14}$ C years BP (Björck and Digerfledt 1982a, b). Two dates 766 refer to isolation owing to concomitant lowering of the Baltic Ice Lake in Blekinge 767 (Björck 1979) and one refers to the timing of the Baltic Ice Lake water-level fall as 768 recorded in Arkona Basin, southern Baltic Sea (Bennike \& Jensen 2013). All ages are 769 here presented with their 1 sigma uncertainty and error bars. Under the assumption 770 of synchronicity between Event 1, the first drainage of the Baltic Ice Lake and the onset 771 of Greenland Stadial 1, the estimated offset between the GICC05 (after converting the 772 b2k age into BP) and the IntCal13 time scales at the transition into Greenland Stadial 7731 is of $30 \pm 22$ years $(1 \sigma)$.

775 Table 1. AMS ${ }^{14} \mathrm{C}$ dates from glacilacustrine varves of the Östergötland master 776 chronology. All dates are based on selected terrestrial plant remains and used to 777 construct the Bayesian wiggle-matching age model presented in this study. 
779 Table 2. Input parameters used in the ice flow/calving model experiments. 


\begin{tabular}{|c|c|c|c|c|c|}
\hline Sample ID & Site & Local Varve Years & ${ }^{14} \mathrm{C}$ age (year) & ${ }^{14} \mathrm{C}$ error ( 1 sigma) & $\begin{array}{l}\text { Used in the } \\
\text { age model }\end{array}$ \\
\hline Ua-11233 & Nedre Emmaren & $2221 \pm 52$ & 10740 & 240 & No \\
\hline Ua-10181 & Gummetorpasjön & $2199 \pm 32$ & 11450 & 240 & No \\
\hline Ua-11234 & Nedre Emmaren & $2146 \pm 23$ & 10885 & 250 & Yes \\
\hline Ua-3131 & Tynn & $2125 \pm 35$ & 10890 & 120 & Yes \\
\hline Ua-10182 & Gummetorpasjön & $2123 \pm 30$ & 11470 & 130 & No \\
\hline Ua-10183 & Gummetorpasjön & $2090 \pm 18$ & 11030 & 120 & Yes \\
\hline Ua-4358 & Hargsjön & $2055 \pm 50$ & 10980 & 100 & Yes \\
\hline Ua-10184 & Gummetorpasjön & $2044 \pm 16$ & 10970 & 90 & Yes \\
\hline Ua-2753 & Hargsjön & $2010 \pm 45$ & 10480 & 150 & No \\
\hline Ua-10185 & Gummetorpasjön & $2009 \pm 16$ & 11230 & 100 & No \\
\hline Ua-4493 & Adlerskogssjön & $2003 \pm 59$ & 10830 & 165 & Yes \\
\hline Ua-4359 & Hargsjön & $1973 \pm 31$ & 10610 & 110 & Yes \\
\hline Ua-10186 & Gummetorpasjön & $1968 \pm 25$ & 11040 & 110 & No \\
\hline Ua-10187 & Gummetorpasjön & $1938 \pm 4$ & 10420 & 220 & Yes \\
\hline Ua-4496 & Glottern & $1856 \pm 50$ & 10585 & 465 & No \\
\hline
\end{tabular}


Table 2

\begin{tabular}{cc}
\hline Parameter/Constant & Value \\
\hline Ice density $-\rho_{i}$ & $900 \mathrm{~kg} \mathrm{~m}^{-3}$ \\
Meltwater density $-\rho_{w}$ & $1000 \mathrm{~kg} \mathrm{~m}^{-3}$ \\
Proglacial water body density $-\rho_{p}$ & $1000 \mathrm{~kg} \mathrm{~m}^{-3}$ \\
Gravitational acceleration $-g$ & $9.8 \mathrm{~m} \mathrm{~s}^{-2}$ \\
Friction exponent $-m$ & 3 \\
Excess floatation fraction $-q$ & 0.09 \\
Glen's flow law exponent $-n$ & 3 \\
Glen's flow law coefficient $-A$ & $2.93 \times 10^{-17} \mathrm{~Pa}^{-3} \mathrm{a}^{-1}$ \\
& $\sim 250 \mathrm{~m}$ \\
Initial grid size & $0.005 \mathrm{a}$ \\
Time step &
\end{tabular}




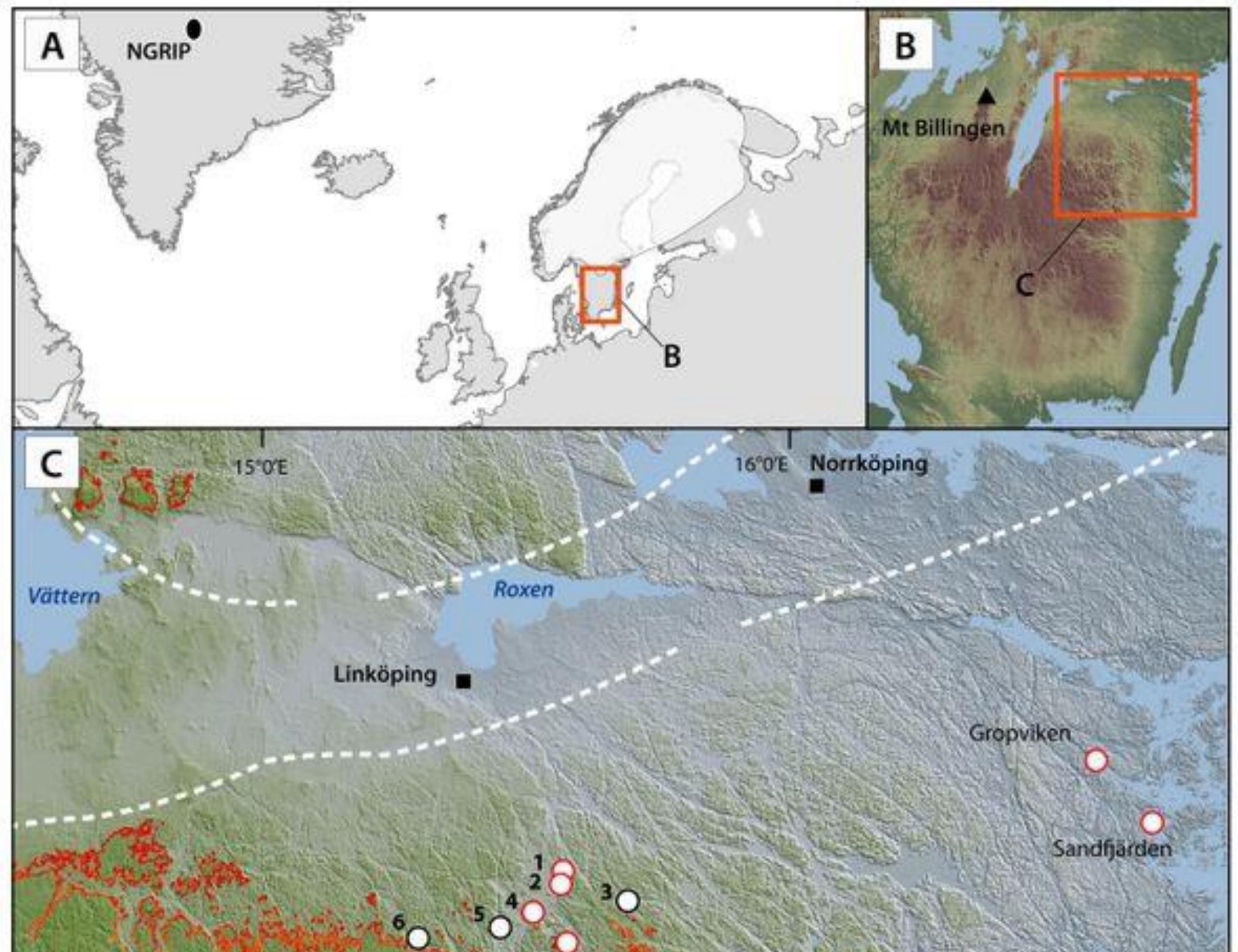


Jărnlunden/Stensvassa

Limmern

Järnlunden/Sonebo

Mjölsjön 2

Mjölsjön 1

$\mathrm{Fi} \xi$

Storsjön

Nătvin

$\longrightarrow 43 \mathrm{a}$ Bjärsjön

$\longrightarrow \quad 42 b$

Glottern 3

$\begin{array}{ll}\longrightarrow & \text { Glottern 2 } \\ & \text { Glottern 1 } \\ & 40\end{array}$

${ }_{-39}^{-39}$

Asunden/Krăgeda

- 37 Răvantorpasjön

$\longrightarrow$
-36

$-35$

Hargsjon 3

$\longrightarrow$ Hargsjön 1

Adlerskogsjön

$\longrightarrow 33$ Adlerskogsjön 2

$\begin{array}{ll}- & 33 \\ - & 32\end{array}$

$-31$

$-29$

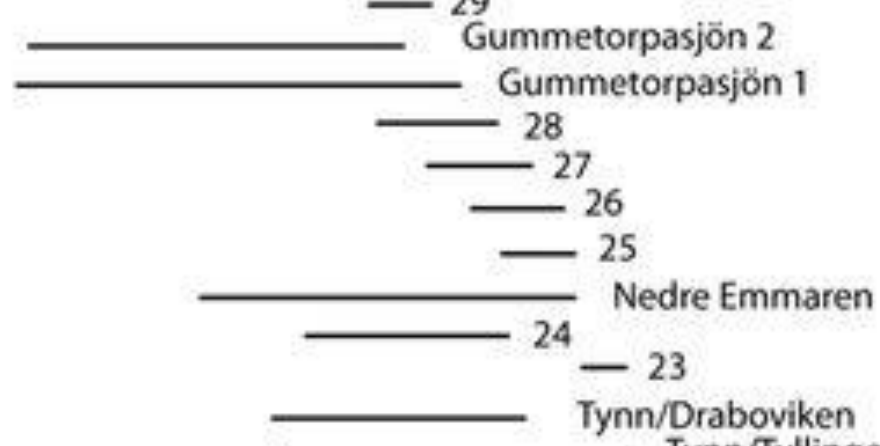

ynn/Draboviken 


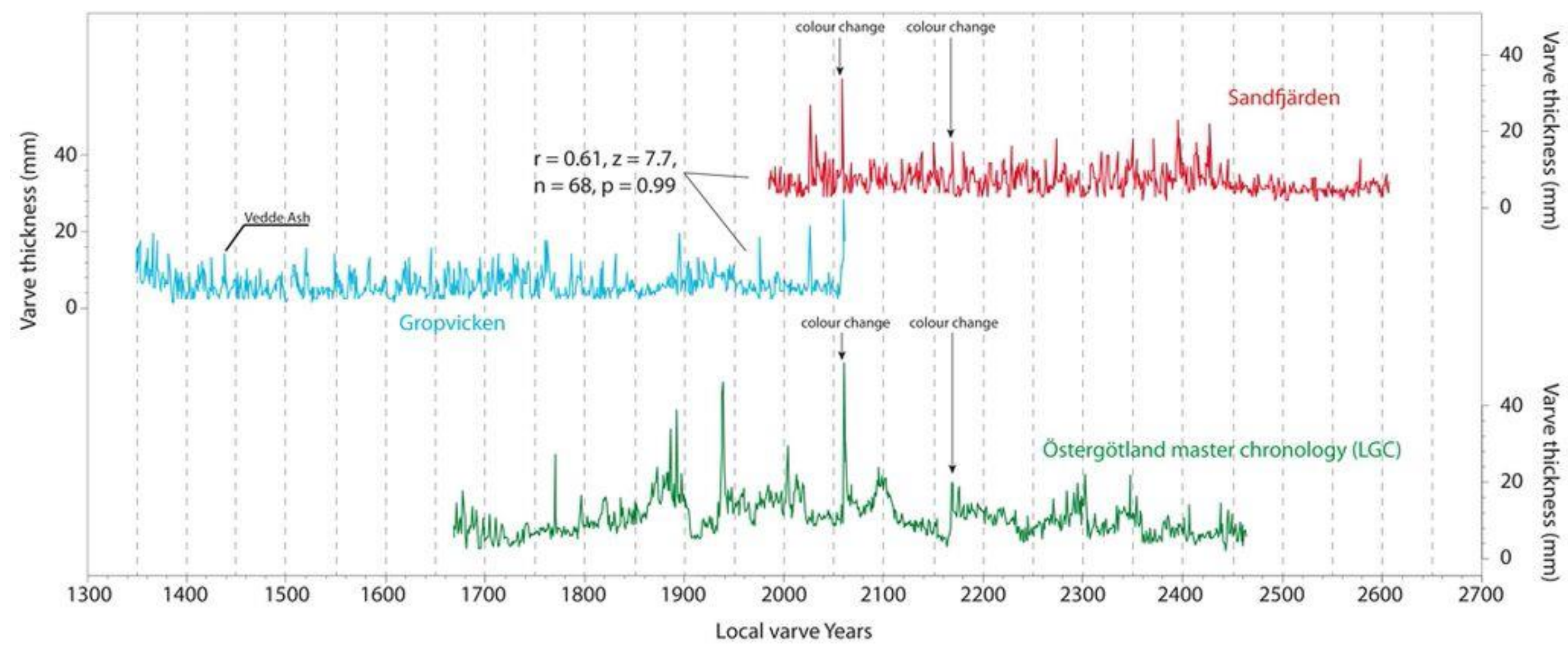



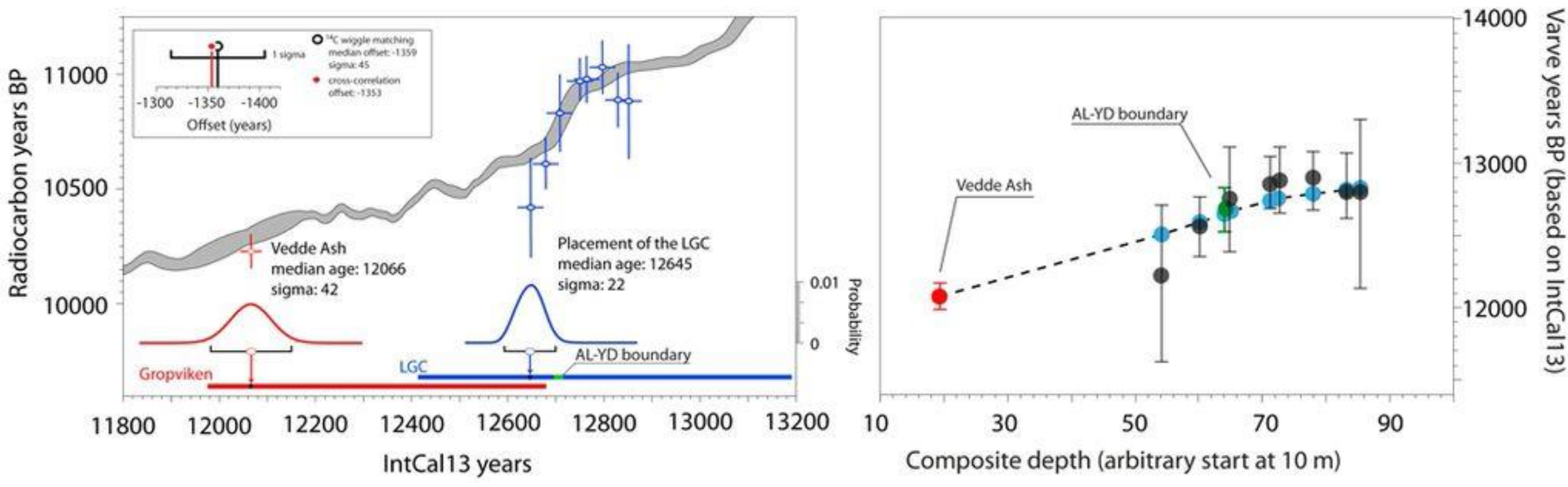


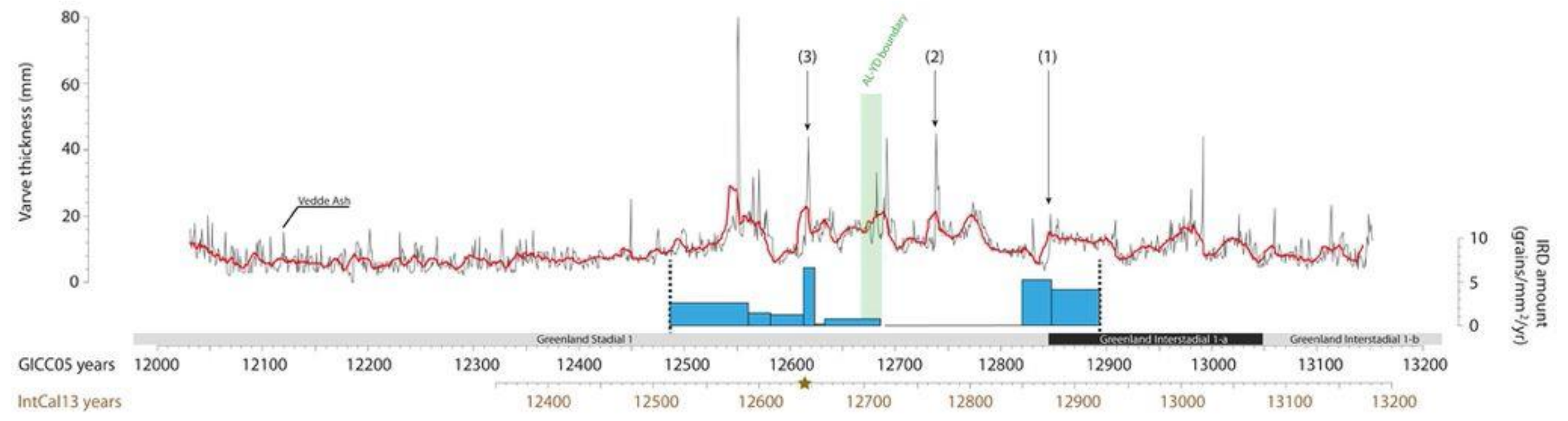




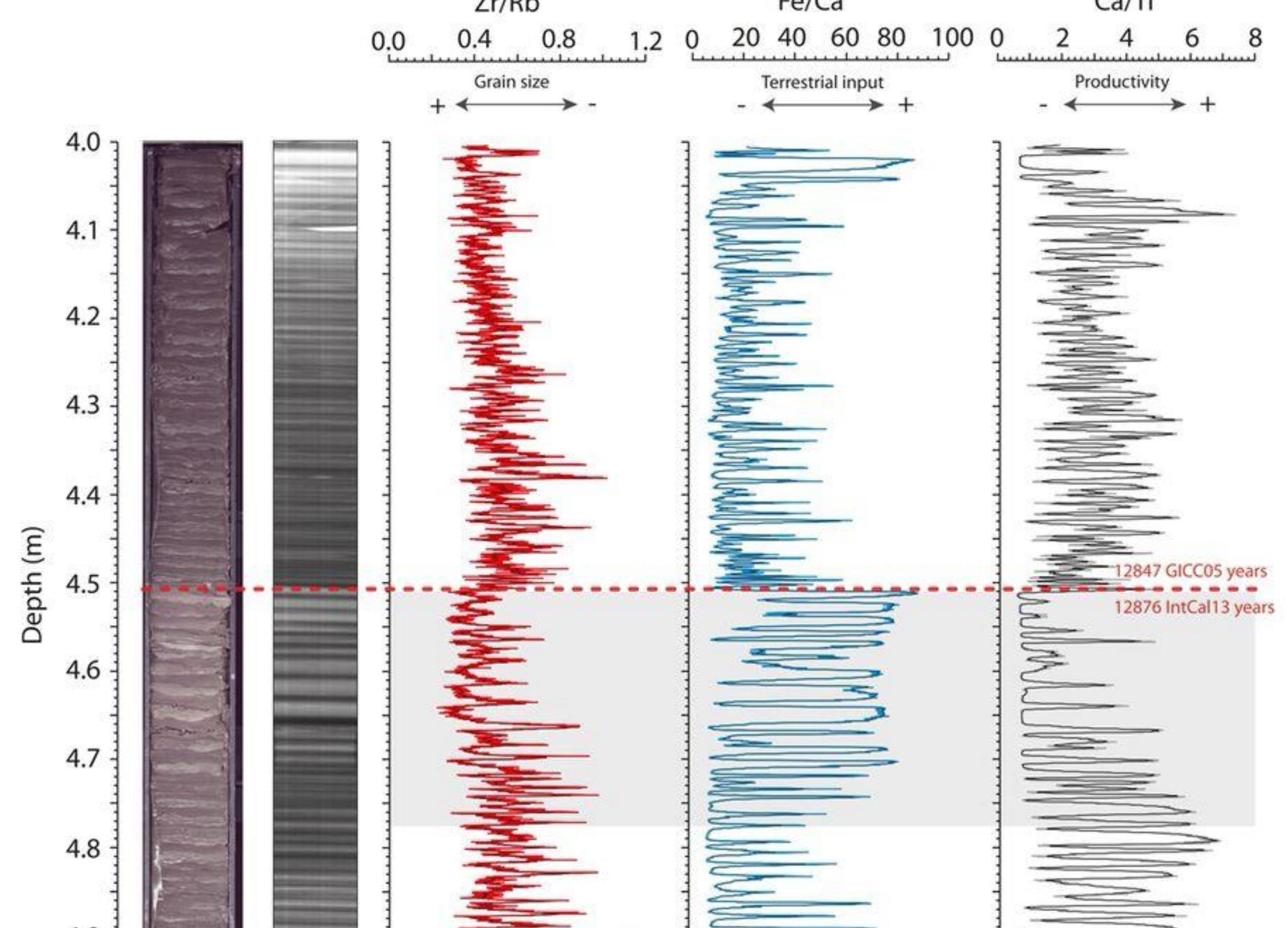



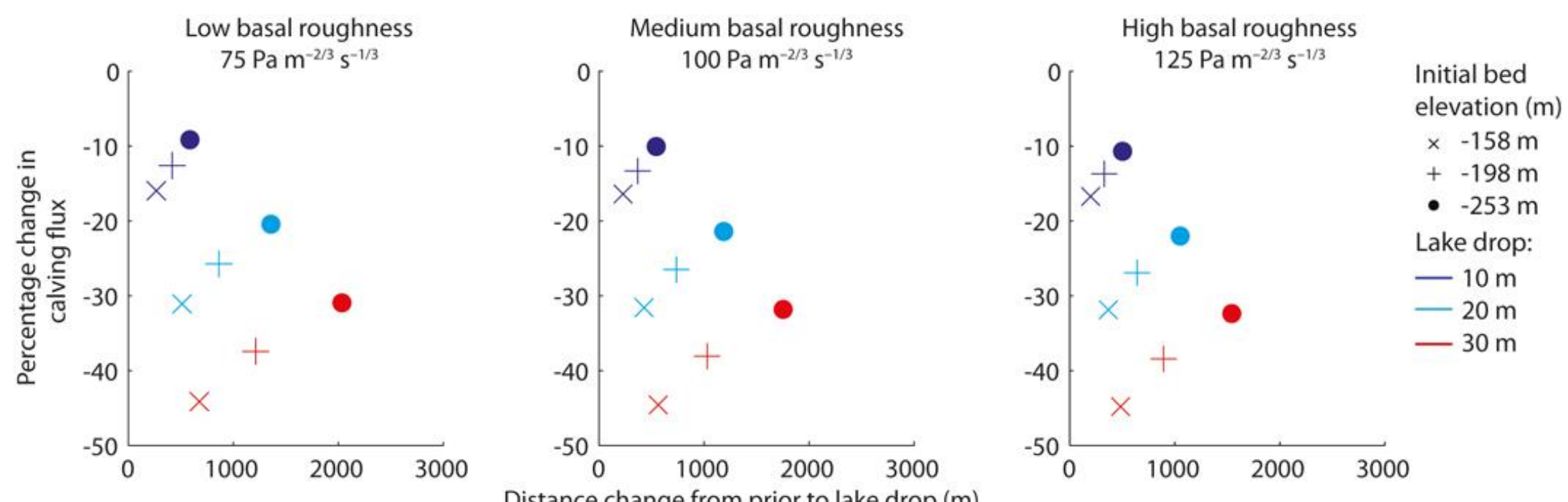


\section{GICC05 years BP}

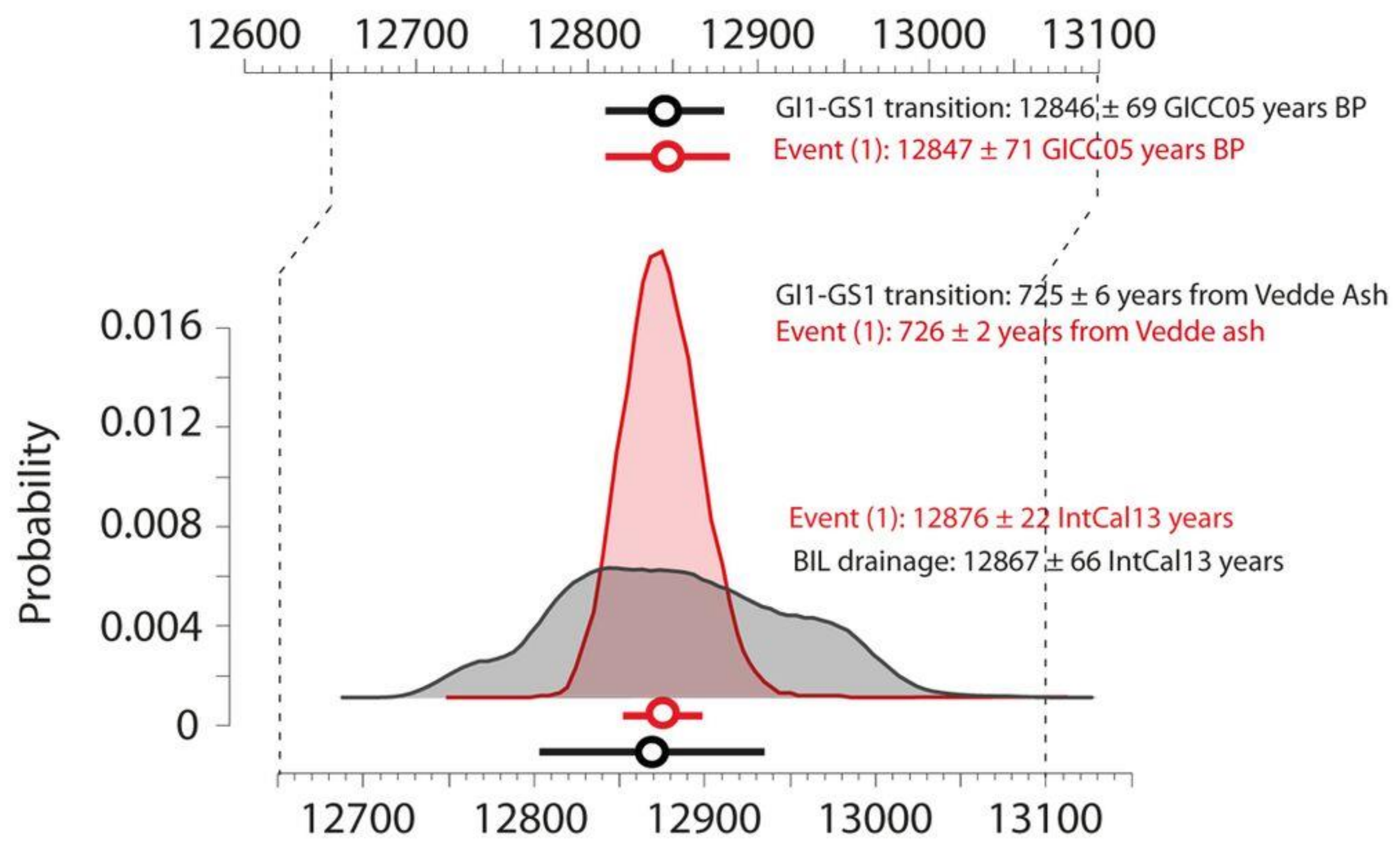

